\title{
THE OBLigation OF LAW SCHOOLS TO TEACH Climate CHANGE LAW
}

\author{
DANIELLE IRELAND-PIPER* AND NICK JAMES ${ }^{\dagger}$
}

\begin{abstract}
Climate change will impact most, if not all, aspects of law and regulation. Law is a key mechanism of social governance, and it has a key role to play in regulating and addressing the causes and consequences of climate change. In the midst of the unfolding climate crisis law schools have a clear and pressing obligation to contribute to efforts to address climate change and its consequences by ensuring climate change law occupies an appropriate place in the law curriculum. In this article we consider the obligation of universities, and law schools in particular, to respond appropriately to the climate crisis in their program offerings. We begin by reflecting on the obligation of law schools and universities to contribute to the public good, an obligation often downplayed given the contemporary emphasis upon the 'job-readiness' of graduates and other neoliberal priorities. We then focus on the obligation of universities and law schools to respond appropriately to climate change. We examine the landscape of climate change law and identify the essential elements of climate change law for inclusion in the law curriculum. And we conclude by identifying examples of ways in which law schools are already incorporating climate change law into their law programs.
\end{abstract}

\section{INTRODUCTION}

While the threat of climate change is widely known and the seriousness of that threat is generally appreciated (deniers notwithstanding), ${ }^{1}$ we commence with a brief recap of our situation:

Earth's climate has changed over the past century. The atmosphere and oceans have warmed, sea levels have risen, and glaciers and ice sheets have decreased in size. The best available evidence indicates that greenhouse gas emissions from human activities are the main cause. Continuing increases in greenhouse gases will produce further warming and other changes in Earth's physical environment and ecosystems. ... Climate change has impacts on ecosystems, coastal systems, fire regimes, food and water security, health, infrastructure and human security. Impacts on ecosystems and societies are already occurring around the world, including in Australia. The impacts will vary from one region to another and, in the short term, can be both positive and

\footnotetext{
Associate Professor, Faculty of Law, Bond University.

Professor and Executive Dean, Faculty of Law, Bond University.

Riley E Dunlap and Aaron M McCright, 'Climate Change Denial: Sources, Actors and Strategies' in Constance Lever-Tracy (ed), Routledge Handbook of Climate Change and Society (Routledge, 2010) 240,240 .
} 
negative. In the future, the impacts of climate change will intensify and interact with other stresses. If greenhouse gas emissions continue to be high, it is likely that the human-induced component of climate change will exceed the capacity of some countries to adapt. ${ }^{2}$

Climate change has important implications for law schools in three key respects.

First, law is a key mechanism of social governance, and as such it has a key role to play in regulating and addressing the causes and consequences of climate change. Law graduates will need to draw upon a thorough understanding of climate change law if they want to practice in what is likely to be an area of increasing importance, ${ }^{3}$ or if they want to participate in or support efforts to reform our legal and social structures in order to better address climate change.

Second, climate change will impact many, if not most, aspects of law and regulation. 4 This means that many fields of legal research will need to engage with climate change either directly or indirectly, and that many law subjects taught at law school will need to acknowledge climate change and its impact upon the legal rules, processes and practices examined in the subject.

Third, and most importantly, law schools have a general obligation to serve the public good, and the public good is served by supporting our community to respond appropriately to climate change via its legal structures and processes. This is achieved by facilitating the creation of a new generation of legal practitioners adequately educated about climate change and its consequences.

The central contention of this article is that, given these three key implications of climate change, law schools have a specific obligation to ensure law students are educated in climate change law during the course of their studies.

The article is presented in four parts. In the Part I we reflect on the obligation of law schools and universities to contribute to the public good, an obligation often downplayed given the contemporary emphasis upon the 'job-readiness' of graduates and other neo-liberal priorities. In Part II, we focus on the obligation of universities and law schools to respond appropriately to climate change. In Part III we identify what should be included in the law curriculum by examining the landscape of climate change law and the implications of climate change for the law generally. Finally, in Part IV, we offer some examples of ways in which law schools are incorporating climate change law into their law programs.

A preliminary matter: this article is premised on the accuracy of the prevailing scientific view that humans 'are at the centre of global climate change:

\footnotetext{
Australian Academy of Science, 'Summary', The Science of Climate Change (Web Page) <https://www.science.org.au/learning/general-audience/science-booklets/science-climatechange/summary>.

Hana Vizcarra, 'Climate Change is Changing the Practice of Law', Harvard Law School Environmental and Energy Law Program (Blog Post, 30 July 2020) <https://eelp.law.harvard.edu/2020/07/climatechange-is-changing-the-practice-of-law-beyond-environmental-law/>.

Richard Lord et al, 'Overview of Legal Issues Relevant to Climate Change' in Richard Lord et al (eds), Climate Change Liability: Transnational Law and Practice (Cambridge University Press, 2011) 23.
} 
their actions cause anthropogenic climate change, and social change is key to effectively responding to climate change'. ${ }^{5}$ We note that not all persons teaching law necessarily accept the scientific consensus on this point. As the United Nations Intergovernmental Panel on Climate Change ('IPCC') observed in 2018:

People with particular political views and those who emphasize individual autonomy may reject climate science knowledge and believe that there is widespread scientific disagreement about climate change, inhibiting support for climate policy. This may explain why extreme weather experiences enhances preparedness to reduce energy use among left- but not right-leaning voters. ${ }^{6}$

Even supposing a legal educator does not accept anthropogenic climate change, it may be that such a person still accepts the warming of the planet (now widely evidenced) and recognises the need for the law to regulate its causes and consequences. Further, disagreement regarding the existence or causes of climate change or the need for climate change law does not affect the actual existence of such a body of law, and even the most climate-change-sceptical of legal educators must accept that employers prefer to see graduates equipped with an understanding of current and future regulatory frameworks. For these reasons, this article does not seek to engage in the debate as to the cause of climate change. We will leave that to the scientists. Here, we simply consider the responsibility of law schools to respond to the prevailing scientific view.

\footnotetext{
Heleen de Coninck et al, 'Strengthening and Implementing the Global Response' in Valérie MassonDelmotte et al (eds), Global Warming of $1.5^{\circ} \mathrm{C}$ : An IPCC Special Report on the Impacts of Global Warming of $1.5^{\circ} \mathrm{C}$ Above Pre-Industrial Levels and Related Global Greenhouse Gas Emission Pathways, in the Context of Strengthening the Global Response to the Threat of Climate Change, Sustainable Development, and Efforts to Eradicate Poverty (IPCC, 2018) 313, 362. See also Charles Vlek and Linda Steg, 'Human Behavior and Environmental Sustainability: Problems, Driving Forces, and Research Topics' (2007) 63(1) Journal of Social Issues 1, 1-19; Thomas Dietz, Paul C Stern and Elke U Weber, 'Reducing Carbon-Based Energy Consumption through Changes in Household Behavior' (2013) 142(1) Daedalus 78, 78-9; ISSC and UNESCO, World Social Science Report 2013: Changing Global Environments (OECD Publishing, 2013) 609; Heide Hackmann, Susanne C Moser and Asuncion Lera St Clair, 'The Social Heart of Global Environmental Change' (2014) 4(8) Nature Climate Change 653, 653-5.

de Coninck et al (n 5) 364 (citations omitted), citing Dan Kahan, 'Fixing the Communications Failure' (2010) 463(7279) Nature 296, 296-7; Saffron J O'Neill et al, 'On the Use of Imagery for Climate Change Engagement' (2013) 23(2) Global Environmental Change 413, 413-21; Charles Adedayo Ogunbode, Yue Liu and Nicole Tausch, 'The Moderating Role of Political Affiliation in the Link Between Flooding Experience and Preparedness to Reduce Energy Use' (2017) 145(34) Climatic Change 445, 445-58; Ding Ding et al, 'Support for Climate Policy and Societal Action are Linked to Perceptions about Scientific Agreement' (2011) 1(9) Nature Climate Change 462, 4626; Aaron M McCright, Riley E Dunlap and Chenyang Xiao, 'Perceived Scientific Agreement and Support for Government Action on Climate change in the USA' (2013) 119(2) Climatic Change 511, 511-18.
} 


\section{Contributing to the Public Good}

Universities have a general obligation to contribute to the public good, ${ }^{7}$ and the public good is served by supporting the community to respond appropriately to climate change. Law schools can achieve this by educating law students about climate change and its consequences.

Contemporary discourse in Australia about the role of universities often downplays the importance of contributing to the public good. Instead, the contemporary discourse is primarily vocational, ${ }^{8}$ in that it prioritises employability as an outcome of higher education, 9 and emphasises the importance of practical and professional skills development within the curriculum. ${ }^{10}$ The dominance of vocationalism is evidenced by the frequent assertion by the Australian government and others that universities' principal responsibility is to produce 'job ready' graduates, ${ }^{11}$ capable of contributing to national productivity, ${ }^{12}$ and the fact that the quality of a university and its teaching are, at least in part, determined by reference to the success of employment outcomes for its graduates, including the proportion of graduates in full-time employment and the salaries they earn. ${ }^{13}$

This emphasis upon the employability of graduates is perhaps understandable - if not inevitable - given the cultural predominance of capitalism and neoliberalism. ${ }^{14}$ The role of universities within the capitalist,

\footnotetext{
See, eg, Simon Marginson, 'Higher Education and Public Good' (2011) 65(4) Higher Education Quarterly 411.

W Norton Grubb and Marvin Lazerson, 'Vocationalism in Higher Education: The Triumph of the Education Gospel' (2005) 76(1) Journal of Higher Education 1.

See, eg, Andrew Trounson, 'Grim Jobs Outlook for New Graduates', The Australian (online, 24 July 2015) <http://www.theaustralian.com.au/higher-education/grim-jobs-outlook-for-newgraduates/news-story/3d6a774ebb995dc9ba3f178c721d50d5>; Hamish Coates, 'Employability: Time For Higher Education Sector to Step Up', The Australian (online, 25 November 2015) <http://www.theaustralian.com.au/higher-education/opinion/employability-time-for-highereducation-sector-to-step-up/news-story/bf2846cd3079752a796fc5981f9a239c>; Zena Hitz, 'Why Rebranding Higher Education as "Job Training" is an Offence to Humanism', New Statesman (online, 21 August 2020) <https://www.newstatesman.com/politics/education/2020/08/whyrebranding-higher-education-job-training-offence-humanism>.

10 See the focus upon different approaches to embedding practical skills in Richard Johnstone and Sumitra Vignaendra, 'Learning Outcomes and Curriculum Development in Law: A Report Commissioned by the Australian Universities Teaching Committee' (Higher Education Group Department of Education, Science and Training, 2003) 166.

${ }^{11} \quad$ Australian Government, 'Job-Ready Graduates Package', Department of Education, Skills and Employment (Web Page, 2021) <https://www.dese.gov.au/job-ready>.

12 See, eg, Simon Birmingham, 'Speech at Ai Group Launch of Graduate Employment Service' (Speech, Ai Group Launch of Graduate Employment Service, 11 October 2016).

13 Quality Indicators for Learning and Teaching, 'Graduate Outcomes Survey - Longitudinal', Surveys (Web Page, 2021) <https://www.qilt.edu.au/surveys/graduate-outcomes-survey--longitudinal-(gos-1)>. See also Margaret Thornton and Lucinda Shannon, " "Selling the Dream": Law School Branding and the Illusion of Choice' (2013) 23(2) Legal Education Review 249, 257-65.

${ }_{14}$ Margaret Thornton, 'Among the Ruins: Law in the Neo-Liberal Academy' (2001) 20 Windsor Yearbook of Access to Justice 3.
} 
neoliberal state is the creation of productive workers trained to transition easily into revenue-generating employment positions. ${ }^{15}$ However, as many critics of vocationalism's dominance have pointed out, the contemporary emphasis upon graduate employability comes at a cost. ${ }^{16}$ These costs include the risk of deemphasising academic rigour, ${ }^{17}$ the devaluing of an education in the liberal arts and humanities, and inadequate attention being paid to teaching critical thinking and the questioning of dominant ideologies, political views and social practices. ${ }^{18}$ Most importantly for the purposes of this article, they also include the deemphasis of the historical obligation of universities to contribute to the public good.

\section{A Universities and the Public Good}

Universities have long been recognised - at least as far back as $1200 \mathrm{AD}$ - as having an obligation to serve the public good. ${ }^{19}$ The notion extends all the way back to the establishment of the very first modern universities in Bologna, Paris

15 A legal education that fails to provide students with the knowledge and skills needed for a successful career in law is portrayed by those who adhere to this view as fundamentally flawed: see, eg, Katherine Towers, 'Law Graduates Not Keeping Up with the Modern World', The Australian (online, 25 May 2016) <http://www.theaustralian.com.au/higher-education/law-graduates-notkeeping-up-with-the-modern-world/news-story/e2092d31bd445d4418d623b3d16a7537>;

Stefanie Garber, 'Law Students Question Value of Their Degree', Lawyers Weekly (online, 3 August 2015) <http://www.lawyersweekly.com.au/news/16923-law-students-question-the-value-ofdegree>; Linda Sheryl Greene, 'Law Schools Need to Better Prepare Their Students', The New York Times (online, 24 September 2015) <http://www.nytimes.com/roomfordebate/2015/09/24/is-thebar-too-low-to-get-into-law-school/law-schools-need-to-better-prepare-their-students $>$.

See in particular the work of Margaret Thornton, including Margaret Thornton, 'Portia Lost in the Groves of Academe Wondering What to Do about Legal Education' (1991) 9(2) Law in Context: A Socio-Legal Journal 9; Margaret Thornton, 'Law as Business in the Corporatised University' (2000) 25(6) Alternative Law Journal 269; Margaret Thornton, 'The Idea of the University and the Contemporary Legal Academy' (2004) 26(4) Sydney Law Review 481; Margaret Thornton, Privatising the Public University: The Case of Law (Routledge, 2012). See also the 2013 special issue of the Legal Education Review focusing upon critical approaches to legal education, including Thornton and Shannon (n 13) 257-65; Paula Baron, 'A Dangerous Cult: Response to "The Effect of the Market on Legal Education"' (2013) 23(2) Legal Education Review 273; Gabrielle Appleby, Peter Burdon and Alexander Reilly, 'Critical Thinking in Legal Education: Our Journey' (2013) 23(2) Legal Education Review 345; Mary Heath and Peter D Burdon, 'Academic Resistance to the Neoliberal University' (2013) 23(2) Legal Education Review 379.

17 William L Twining, 'The Idea of Juristic Method: A Tribute to Karl Llewellyn' (1993) 48(1) University of Miami Law Review 119, 146. Non-legal scholars have been concerned with such issues for a very long time. Cardinal John Henry Newman in his book The Idea of a University (University of Notre Dame Press, 1852) acknowledged that the training of professional people came within the function of a university, but insisted that the education of the intellect was the essential function of a university. See generally Nickolas John James, 'The Marginalisation of Radical Discourses in Australian Legal Education' (2006) 16(1-2) Legal Education Review 55.

$19 \quad$ Michael Cuthill et al, 'Universities and the Public Good: A Review of Knowledge Exchange Policy and Related University Practice in Australia' (2014) 56(2) Australian Universities Review 36, 36. See also Adrianna Kezar, Anthony C Chambers and John C Burkhardt (eds), Higher Education for the Public Good: Emerging Voices from a National Movement (John Wiley \& Sons, 2015). 
and Oxford. ${ }^{20}$ For centuries, the distance - both physical and metaphorical between the university and the worlds of commerce and politics was valued and protected. In order to avoid being influenced by political and commercial imperatives, scholars sought to maintain a distance between the 'profane' worlds of politics and commerce and the 'sacred' academy. From their 'ivory tower', they could observe and evaluate social events from an elevated, neutral, disinterested perspective. ${ }^{21}$

The role of the university in serving the public good included not only the preservation of humanity's knowledge and wisdom, the transmission of that knowledge and wisdom from one generation to the next, and the nurturing and growth of that knowledge and wisdom through meticulous and rigorous research and scholarship. It also included the dedication of the university's expertise to serving the needs of the community, while simultaneously seeking to preserve the distance from community concerns required to maintain the isolation required for scholarship.22

The particular way in which universities contribute to the public good has taken a variety of forms over the years, ${ }^{23}$ including engaging with private, public and community sector stakeholders to contribute to social justice and development; ${ }^{24}$ focussing on public policy; ${ }^{25}$ interacting with industry; ${ }^{26}$ and addressing the 'grand challenges' of the $21^{1 \mathrm{tt}}$ century. ${ }^{27}$ Today when the public role of universities receives attention in public discourse the focus is often upon the universities' obligation to contribute to economic prosperity, ${ }^{28}$ and universities themselves are likely to refer to their contributions to the public good to justify public funding. 29

Michael Cuthill, 'A "Civic Mission" for the University: Engaged Scholarship and CommunityBased Participatory Research' in Lorraine McIlrath, Ann Lyons and Ronaldo Munck (eds), Higher Education and Civic Engagement: Comparative Perspectives (Palgrave Macmillan, 2012) 81, 81-2.

Steven Shapin, 'The Ivory Tower: The History of a Figure of Speech and its Cultural Uses' (2012) 45(1) British Journal for the History of Science 1.

See, eg, Paul Chatterton, 'The Cultural Role of Universities in the Community: Revisiting the University' (2000) 32(1) Environment and Planning A: Economy and Space 165; Catherine Manathunga, 'Excavating the Role and Purpose of University Education in the Postmodern Age: Historical Insights from the South' (2017) 1(1) Policy Reviews in Higher Education 69.

Michael Cuthill et al (n 19) 37.

Cuthill (n 20) 81-99.

Niels Mejlgaard et al, Monitoring Policy and Research Activities on Science in Society in Europe (MASIS) (Final Synthesis Report, 2012).

Shiri M Breznitz and Maryann P Feldman, 'The Engaged University' (2012) 37 Journal of Technology Transfer 139.

Michael Barber, Katelyn Donnelly and Saad Rizvi, An Avalanche is Coming: Higher Education and the Revolution Ahead (Institute for Public Policy Research, 2013).

Belinda Robinson, 'Strong Tertiary Sector the Engine Room of Australia's Prosperity', The Australian (online, 1 June 2016) <http://www.theaustralian.com.au/higher-education/opinion/ strong-tertiary-sector-the-engine-room-of-australias-prosperity/news-

story/94e1b536f7b59d01eb951f1f34237c60>. 
The wider public still has an expectation that universities will take responsibility for contributing to the public good, an expectation that has apparently increased as a result of the COVID-19 pandemic. A recent analysis of Australian Leadership Index ('ALI') data revealed that, in contrast to the government's instrumental view of education and its focus on producing 'jobready graduates', the public now takes a wider view of education as a public good. In most communities, 'public education, such as public schools and universities, is understood as serving the interests of the many, not the few.' 30

It seems that despite the vocational and instrumental focus of government, the obligation of universities to contribute to the public good is still valued. As Solbrekke and Sugrue recently explained at length, the purpose of higher education is both for public good and as a public good, and that universities have 'a social and moral responsibility broader than merely reporting on predetermined, transparent and quantifiable quality criteria and learning outcomes'. ${ }^{31}$

\section{B Law Schools and the Public Good}

What is the status of the obligation to contribute to the public good within the discipline of law? Law schools in Australia were initially controlled by the legal profession and their role was one that focussed upon training the next generation of practitioners. ${ }^{32}$ In the mid- $20^{\text {th }}$ century, there was a deliberate effort to distance the academy from the profession, and achieve greater ideological alignment between the law school and other academic disciplines. ${ }^{33}$ The dominant ideology within the law school became one that placed greater value upon scholarship and doctrine. It is too much, however, to say that law schools recommitted to the traditional role of the university. Instead, the focus of the law school narrowed, and the priority became the transmission of doctrine and, specifically, the prescribed areas of knowledge known as the 'Priestly 11'.34

It was not until the 1970 s and 1980 s, and the emergence of a critical or radical movement within law schools, that calls for a greater emphasis upon the social

Melissa A Wheeler et al, 'Pandemic Widens Gap Between Government and Australians' View of Education', The Conversation (online, 12 November 2020) <https://theconversation.com/ pandemic-widens-gap-between-government-and-australians-view-of-education-148991>.

31 Tone Dyrdal Solbrekke and Ciaran Sugrue, Leading Higher Education As and For Public Good: Rekindling Education as Praxis Tone (Routledge, 2020) 166.

32 Linda Martin, 'From Apprenticeship to Law School: A Social History of Legal Education in Nineteenth Century New South Wales' (1986) 9(2) University of New South Wales Law Journal 111, $121,135-6$.

33 Judith Lancaster, The Modernisation of Legal Education: A Critique of the Martin, Bowen and Pearce Reports (Centre for Legal Education, 1993) 2.

34 Dennis Pearce, Enid Campbell and Don Harding, Australian Law Schools: A Discipline Assessment for the Commonwealth Tertiary Education Committee (Australian Government Publishing Service, 1987). 
obligation of law schools began to be heard. ${ }^{35}$ Critical, radical and feminist scholars called for social justice and law reform to be included in the law curriculum. These calls were initially met with resistance, ${ }^{36}$ but the efforts of such scholars persisted and while in some law schools they remain at the margins, in many law schools, critical perspectives on the law and initiatives focussed on social justice and public service are now explicitly promoted. ${ }^{37}$

The role that law schools can play in contributing to the public good includes more than the traditional responsibility for preserving and enhancing disciplinary knowledge. It also includes using the talent and expertise among its students, scholars and professional partners to assist the community. There are, of course, social and political contingencies that motivate law schools to disregard this role. ${ }^{38}$ These include School and Faculty performance frequently being measured according to law-student employability; pressure from law students to focus upon assisting them to find employment; and restrictions upon spending and its limitation to revenue generating initiatives. ${ }^{39}$ However, despite the pressures upon law-school leadership to focus upon revenue generation through student recruitment, research funding and philanthropic support, enhancing customer or student satisfaction, and cost minimisation, ${ }^{40}$ many law schools continue to engage in activities concerned primarily (although not always solely) with serving the public good.

Legal research and scholarship are themselves ways in which law schools contribute to the public good. Research productivity for a law school, like most academic units, is predominantly measured in terms of quantum of quality publications, higher-degree research completions, and externally sourced grant income. These indicators typically inform the Key Performance Indicators by

Nickolas John James, 'The Marginalisation of Radical Discourses in Australian Legal Education' (2006) 16(1-2) Legal Education Review 55.

36 Hilary Charlesworth quotes an article in the Australian Financial Review, which argues that radical legal theorists should not be allowed to teach in law schools, because 'it is their avowed intention not to teach law in a way that will be useful to practitioners in the actual legal system'; that Critical Legal Studies (CLS) 'represents the loony Left of the legal profession'; and that its advocates 'have many of the features of a fundamentalist sect, being intolerant of democracy and willing to employ intimidation and misrepresentation': 'New Directions in Legal Theory: Critical Legal Studies' (1989) 63 Law Institute Journal 248, 248, quoting Padraic P McGuinness, 'The Trouble with Law School', Australian Financial Review (Sydney, 1989).

37 See, eg, Southern Cross University, 'Welcome to the Faculty of Business, Law and Arts', Business, Law and Arts (Web Page) <https://www.scu.edu.au/school-of-law-and-justice/>.

38 The explanation of historical phenomena by way of identification of multiple 'contingencies' rather than a single 'cause' is consistent with Foucault's approach to historical analysis. Instead of seeking final causes and ultimate truths, Foucault recommended that the focus be upon identifying the conditions of a discourse's production. When he analysed knowledge and discourses, the question for Foucault was: 'How are [they] historically possible, and what are the historical consequences of their existence?': Colin Gordon, 'Afterword' in Colin Gordon (ed), Michel Foucault. Power/Knowledge: Selected Interviews and Other Writings 1972-1977 (Pantheon Books, 1981), 230-1. Nickolas James, 'Power-Knowledge in Australian Legal Education: Corporatism's Reign' (2004) 26(4) Sydney Law Review 587. Ibid. 
which the performances of law schools and law deans are judged. Similarly, the performance of individual academics is evaluated by reference to their research productivity, along with their teaching performance and fulfilment of service commitments. The motivation of many academics to engage in research and scholarship is not only extrinsic, such as the desire to meet their employer's performance expectations and earn rewards such as tenure, promotion, merit pay, travel provisions, payment of incidental expenses, clerical assistance, and special privileges. It is also intrinsic, including liking problem solving, enjoying a sense of competence and engaging in research for its own sake. Academic scholars seek answers to research questions because they have an intellectual interest in the subject matter or in the outcome of the research, and because they wish to participate in the collective academic endeavour of expanding, extending and renewing human knowledge about and understanding of the world. ${ }^{41}$

Many law schools operate or participate in law clinics where law students work alongside law teachers and legal practitioners to deliver legal services to members of the community on a pro bono basis. $4^{2}$ There are several positive outcomes of such participation. The law students benefit from engaging in a clinical learning experience. The law school benefits from engagement with local legal practitioners. The community benefits from the provision of legal assistance to those who might otherwise be unable to access support. ${ }^{43}$ In turn, this contributes to improving access to justice and strengthening the rule of law.

Clinics are not the only way in which law schools and legal academics contribute to achieving social justice. Many law schools also engage in and support community legal education initiatives, ${ }^{44}$ hackathons, ${ }^{45}$ and unjust imprisonment causes such as the Innocence Project. ${ }^{46}$

Law schools can also contribute to the public good by offering subjects and programs that educate students about specific issues of public importance such as climate change, and by exploring how the law can be used to mitigate and address the impact and consequences of such issues. The next section investigates this proposition in more detail, with a specific focus upon climate change.

$41 \quad$ Paul Blackmore and Camille B Kandiko, 'Motivation in Academic Life: A Prestige Economy' (2011) 16(4) Research in Post-Compulsory Education 399.

42 Adrian Evans et al, Australian Clinical Legal Education: Designing and Operating a Best Practice Clinical Program in an Australian Law School (ANU Press, 2017).

43 Adrian Evans et al, Best Practices Australian Clinical Legal Education (Australian Government Office for Learning and Teaching, 2012).

44 Suzie Forell and Hugh M McDonald, 'Community Legal Education and Information: Model Priorities and Principles' [2017] 25 (June) Justice Issues 1.

45 'Disrupting Law National', The Legal Forecast (Web Page) <https://www.thelegalforecast.com/ disrupting-law-national>.

46 'Our Work', Innocence Project (Web Page) <https://innocenceproject.org/about/\#ourwork>. 


\section{iII The Obligation To Teach Climate LaW}

We have already considered some of the ways in which commentators call upon universities to serve their communities. More recently, commentors have argued that universities have a role to play in addressing the causes and consequences of climate emergencies.47 As Butler et al explain, '[e]ducational, learning and awareness-building institutions can help strengthen the societal response to climate change'. ${ }^{8}$ Universities have the capacity to assist and support communities to respond to climate change by enhancing the community's understanding of climate change and its consequences and by facilitating improvement in the community's ability to adapt to change. Both are required to ensure an effective response to climate change. 49

Pressure upon universities to do more to respond to climate change includes demands and expectations by students for a greater emphasis upon the climate crisis in their courses. A 2020 study by Cambridge International surveyed more than 11,000 students aged 13 to 19 in the US, Spain, India, the United Arab Emirates ('UAE'), South Africa, China, India, Indonesia, and the United Kingdom ('UK'). In this study, 26 per cent of the students who responded to the survey said they saw climate change as the biggest issue facing the world today, and 31 per cent complained that the courses and program in which they were currently enrolled paid inadequate attention to the issue of climate change..$^{50}$

Pressure is also exerted by public entities such as the United Nations ('UN'). The UN secretary general, António Guterres, speaking at a World Leaders Forum on climate change at Columbia University on 2 December 2020, called on the world to take urgent action to combat climate change and praised the work of universities as 'essential to our success' ${ }^{51}$ He challenged all organisations to examine their own contribution to carbon neutrality, and explained that in the

47 See, eg, Justin Bakor, 'Universities Have a Key Role to Play in Bushfire Recovery', The Australian (online, 22 January 2020) <https://www.theaustralian.com.au/higher-education/universitieshave-a-key-role-to-play-in-bushfire-recovery/newsstory/9e364b82a53565a1d2a5ca347eafdc9d>. de Coninck (n 5) 362, citing JRA Butler et al, 'Scenario Planning to Leap-Frog the Sustainable Development Goals: An Adaptation Pathways Approach' (2016) 12 Climate Risk Management 83.

49 Le Thi Hong Phuong, G Robbert Biesbroek and Arjen EJ Wals, 'The Interplay between Social Learning and Adaptive Capacity in Climate Change Adaptation: A Systematic Review' (2017) 82(1) Wageningen Journal of Life Sciences 1.

50 Cambridge Assessment International Education, 'Cambridge Global Perspectives Survey Results', Cambridge Global Perspectives (Web Page, 2020) <https://www.cambridgeinternational.org/ programmes-and-qualifications/cambridge-global-perspectives/survey-results/>.

51 António Guterres, 'State of the Planet' (Speech, Columbia University, 2 December 2020) <https://www.un.org/sg/en/content/sg/speeches/2020-12-02/address-columbia-universitythe-state-of-the-planet $>$. 
case of universities this means researching solutions as well as cutting their own carbon footprint and divesting from fossil fuels. ${ }^{52}$

Many universities have responded to these pressures, and the increasing interest in environmental programs, not only by introducing new programs, 53 but by publicly committing to prioritising climate change, environmentalism and sustainability in their program design and delivery and/or their planning and operations. Victoria University, for example, recently announced plans to embed planetary health ('the examination of human health through the prism of the natural systems that sustain life') across the entire suite of the university's activities. ${ }^{54}$ Many other universities have identified sustainability as a strategic priority and committed to the UN Sustainable Development Goals. ${ }^{55}$

What about law schools? Commentators have already called upon legal practitioners to do more to address climate change. One way in which they can do so is by taking on climate-related pro bono work. Those who do so 'will not only be able to help mitigate the risk or impact of such environmental challenges, ... but also adhere to the ... underlying duty of legal practice: to improve access to justice. ' ${ }^{6}$ The Australian Pro Bono Centre identified 15 ways in which lawyers can engage in pro bono work that serves to combat the climate crisis:

1. Running strategic climate litigation

2. Working on law reform activities

3. Offering commercial legal advice to not-for-profit organisations and social enterprises

4. Establishing a climate justice clinic in collaboration with a university

5. Providing a secondee to a civil society organisation working to combat climate change

Brendan O'Malley, 'Universities "Essential" to Climate Action, Says UN Chief', University World News (online, 5 December 2020) <https://www.universityworldnews.com/post.php?story= $20201204092017670>$.

Evan Young, 'More and More Uni Students in Australia are Choosing to Study the Environment', SBS News (online, 3 March 2020) <https://www.sbs.com.au/news/more-and-more-unistudents-in-australia-are-choosing-to-study-the-environment $>$. John Ross, 'Australian University Adopts "Planetary Health" as Raison D'être', Times Higher Education (online, 13 March 2020) <https://www.timeshighereducation.com/news/australianuniversity-adopts-planetary-health-raison-detre>.

55 United Nations, 'Take Action for the Sustainable Development Goals', Sustainable Development Goals (Web Page) <https://www.un.org/sustainabledevelopment/sustainable-developmentgoals/>; SDSN Australia, New Zealand \& Pacific, 'Getting Started with the SDGs in Universities', Sustainable Development Solutions Network: A Global Initiative for the United Nations (Web page) $<$ http://ap-unsdsn.org/regional-initiatives/universities-sdgs/university-sdg-guide/>. Weekly (online, 31 August 2020) <www.lawyersweekly.com.au/biglaw/29316-lawyers-musthelp-address-climate-crisis-through-pro-bono-work> . 
6. Providing legal assistance to Indigenous peoples who are disproportionately affected by the climate crisis

7. Conducting legal research about the intersection between human rights and climate change

8. Providing legal advice, information and advocacy to those fighting climate change

9. Providing legal information and advice to those affected by a natural disaster

10. Offering immigration law advice to people displaced by the effects of climate change

11. Giving legal support to NGOs and developing country delegations in international climate change negotiations

12. Providing community legal education

13. Providing legal assistance to communities particularly affected by the climate crisis

14. Delivering training to community lawyers

15. Expanding the role of the pro bono lawyer by embedding climate transition and environmental factors in commercial decision-making 57

In December 2020, the University of Western Australia Public Policy Institute launched the Preparedness Report. The report highlighted the nature and extent of retooling in six fields in response to climate change: engineering, architecture, law, economics, healthcare and oceanography..$^{58}$ In relation to the field of law, it noted:

Academic law is heavily exposed, and its challenges ... boil down to the laws and regulations that can be introduced to reduce emissions and assist people, species and ecosystems vulnerable to climate change. It is a question of intergenerational justice. ${ }^{59}$

Law schools can also contribute to efforts to respond to climate change by including climate change law in the curriculum. ${ }^{60}$ By doing so they will not only prepare law students for what is likely to be an increasingly important area of legal practice, ${ }^{61}$ they will empower law students to themselves contribute to the

Australian Pro Bono Centre, Pro Bono Guide to the Climate Crisis (Online Report, 2020) 6 <https://www.probonocentre.org.au/climate-change-guide/>.

Shamit Saggar, 'How Universities and Professions are Preparing to Meet the Climate Challenge', The Conversation (online, 9 December 2020) <https://theconversation.com/how-universitiesand-professions-are-preparing-to-meet-the-climate-challenge-151662>.

Ibid.

Ling Chen, 'Canadian Law Schools Must Do Their Part to Help Combat Climate Change', Policy Options Politiques (online, 18 February 2020) <https://policyoptions.irpp.org/magazines/february2020/canadian-law-schools-must-do-their-part-to-help-combat-climate-change/>.

See, eg, Baker McKenzie, 'Environment \& Climate Change', Expertise (Web Page) <https://www.bakermckenzie.com/en/expertise/practices/environment-and-climate-change>. 
public good by using the law to respond to and mitigate the effects of climate change. In the next section we examine in detail the core content of climate change law.

\section{The Content of Climate Change LaW}

It is a central contention of this article that law schools have an obligation to respond to climate change by, inter alia, including 'climate change law' in the law curriculum. In this section we identify what we consider to be the baseline scope and content of climate change law.

The first known scientific article discussing the possibility of global warming as a result of carbon dioxide emissions was published in 1896.62 Today, climate change law exists at the intersection of a number of legal disciplines, including international law, environmental law, energy law, and business law. ${ }^{63}$ It encompasses a considerable number of international and domestic instruments, agreements, initiatives, entities, and processes, as well as considerations of the ways in which a variety of legal doctrines, fields, and areas of practice are impacted by climate change. While it will not always be possible for a law program to include a comprehensive analysis of every aspect of climate change law, there are elements of climate change law that, in our view, form the 'bare minimum' for inclusion in the law curriculum. These are the key climate change institutions and instruments and an examination of the broader impacts of climate change on the law generally. In other words, the law curriculum should include consideration of both 'climate change law' and 'climate change and the law'.

\section{A Climate Change Law: Key Institutions and Instruments}

The body of law considered 'climate change law' is primarily comprised of international, environmental, and energy law. Key institutions include the Intergovernmental Panel on Climate Change ('IPCC'), and significant instruments include the United Nations Framework Convention on Climate Change ('UNFCCC'), ${ }^{64}$

62 Svante Arrhenius, 'On the Influence of Carbonic Acid in the Air Upon the Temperature of the Ground' (1896) 41(251) London, Edinburgh, and Dublin Philosophical Magazine and Journal of Science 237, cited in Jacqueline Peel, 'Climate Change Law: The Emergence of a New Legal Discipline' (2008) 32(3) Melbourne University Law Review 922, 924.

63 John C Dernbach and Seema M Kakade, 'Climate Change Law: An Introduction' (2008) 29(1) Energy Law Journal 1, 2.

64 United Nations Framework Convention on Climate Change, opened for signature 4 June 1992, 1771 UNTS 107 (entered into force 21 March 1994) ('UNFCCC'). 
the Kyoto Protocol, ${ }^{65}$ the Doho Amendment, ${ }^{66}$ and the Paris Agreement. ${ }^{67}$ Emissions Trading Schemes also form an important part of the climate change legal framework, as do domestic legal frameworks, such as planning and energy laws and laws setting emissions targets. For example, in late 2019 New Zealand enacted the Climate Change Response (Zero Carbon) Amendment Act 2019, which set a target of net zero by 2050 for $\mathrm{CO} 2$ emissions and established an independent expert body, the Climate Change Commission. ${ }^{68}$ To date, only four Australian jurisdictions have passed specific legislation to promote action on climate change, including the abatement of GHG emissions (mitigation) and reducing the impacts of actual or projected climate change (adaptation). These are the ACT, South Australia, Tasmania and Victoria.

\section{The IPCC}

The IPCC was established in 1998 by the World Meteorological Organisation and the United Nations Environmental Program, and was endorsed by the General Assembly of the United Nations. ${ }^{69}$ The stated objective of the IPCC is to 'provide governments at all levels with scientific information that they can use to develop climate policies. ${ }^{70}$ Reports produced by the IPCC are used as 'a key input into international climate change negotiations. ${ }^{17}$ At the time of writing, the IPCC has 195 member states. ${ }^{72}$ Since 1988, in addition to specific reports, the IPCC has delivered five full Synthesis Assessment Reports:

- The First Assessment Full and Synthesis Report ('AR1') in 1990;73

- The Second Assessment Full and Synthesis Report ('AR2') in 1995;74

Kyoto Protocol to the United Nations Framework Convention on Climate Change, opened for signature 16 March 1998, 2303 UNTS 162 (entered into force 16 February 2005) ('Kyoto Protocol'). Doha Amendment to the Kyoto Protocol, opened for signature 8 December 2012, [2016] ATNIF 24 (entered into force 31 December 2020). Paris Agreement, opened for signature 22 April 2016, [2016] ATS 24 (entered into force 4 November 2016).

Ministry of the Environment, 'Climate Change Response (Zero Carbon) Amendment Act 2019', Acts and Bills (Web Page, April 2021) <https://environment.govt.nz/acts-and-regulations/acts/climate -change-response-amendment-act-2019/>. Protection of Global Climate for Present and Future Generations of Mankind, GA Res 43/53, UN Doc A/RES/43/53 (6 December 1998).

'About the IPCC', IPCC (Web Page) <https://www.ipcc.ch/about/> . Ibid.

'List of IPCC Member Countries', IPCC (Web Page, 2019) <https://www.ipcc.ch/site/assets/ uploads/2019/02/ipcc_members.pdf >.

73 'FAR Climate Change: The IPCC Response Strategies', IPCC (Web Page) <https://www.ipcc.ch/ report/ar1/wg3/>.

74 'IPCC Second Assessment', IPCC (Web Page, 2018) <https://www.ipcc.ch/report/ipcc-secondassessment-full-report/>; Intergovernmental Panel on Climate Change, 'IPCC Second Assessment', WMO-UNEP (Online Report, 1995) <https://www.ipcc.ch/site/assets/uploads/2018/ 06/2nd-assessment-en.pdf>. 
- The Third Assessment Report and Synthesis ('AR3') in 2001;75

- The Fourth Assessment Full and Synthesis Report ('AR4') in 2007;76 and,

- The Fifth Assessment Full and Synthesis Report ('AR5') in 2014. ${ }^{77}$

The IPCC describes its reports as 'the most comprehensive scientific reports about climate change produced worldwide' ${ }^{78}$ At the time of writing, the IPCC is now in its sixth assessment cycle and will deliver its Sixth Assessment Report (AR6) in 2022.79

One of the more recent reports of the IPCC was in response to an invitation in the 'Decision of the 21st Conference of Parties of the United Nations Framework Convention on Climate Change to adopt the Paris Agreement'..$^{80}$ That invitation asked the IPCC to report 'on the impacts of global warming of $1.5^{\circ} \mathrm{C}$ above preindustrial levels and related global greenhouse gas emission pathways. ${ }^{\prime} 1$

In so doing, the IPCC reported:

Human activities are estimated to have caused approximately $1.0^{\circ} \mathrm{C}$ of global warming above pre-industrial levels, with a likely range of $0.8^{\circ} \mathrm{C}$ to $1.2^{\circ} \mathrm{C}$. Global warming is likely to reach $1.5^{\circ} \mathrm{C}$ between 2030 and 2052 if it continues to increase at the current rate..$^{82}$

The report then concluded that such an increase would result in '[c]limaterelated risks to health, livelihoods, food security, water supply, human security, and economic growth', ${ }^{83}$ The IPCC plays a key role in informing the global response to climate change, and as such the law curriculum should include information on the IPCC and its various activities. The law curriculum should also include an examination of the key legal instruments described in the following sections to ensure appropriate legal literacy in graduates.

'TAR Climate Change 2001: Synthesis Report', IPCC (Web Page) $<$ https://www.ipcc.ch/report/ar3/syr/>. See also Daniel L Albritton et al, 'Climate Change 2001: Synthesis Report', IPCC (Report, 2001) <https://www.ipcc.ch/site/assets/uploads/2018/05/SYR _ TAR_full_report.pdf $>$.

'AR4 Climate Change 2007: Synthesis Report', IPCC (Web Page) <https://www.ipcc.ch/report/ ar4/syr/>.

'AR5 Synthesis Report: Climate Change 2014', IPCC (Web Page) <https://www.ipcc.ch/report/ ar $5 /$ syr/ $>$.

'History of the IPCC', IPCC (Web Page) <https://www.ipcc.ch/about/history/>.

'AR6 Synthesis Report: Climate Change 2022', IPCC (Web Page) <https://www.ipcc.ch/report/ sixth-assessment-report-cycle/>.

Valérie Masson-Delmotte et al, 'Summary for Policymakers', in Valérie Masson-Delmotte et al (eds), Global Warming of $1.5^{\circ} \mathrm{C}$ : An IPCC Special Report on the Impacts of Global Warming of $1.5^{\circ} \mathrm{C}$ Above Pre-Industrial Levels and Related Global Greenhouse Gas Emission Pathways, in the Context of Strengthening the Global Response to the Threat of Climate Change, Sustainable Development, and Efforts to Eradicate Poverty (IPCC, 2018) 1, 4.

Report of the Conference of the Parties on its Twenty-First Session, held in Paris from 30 November to 13 December 2015, FCCC Dec 1/CP.21, UN Doc FCCC/CP/2015/10/Add.1 (29 January 2016) pt II [21].

Masson-Delmotte et al (n 80) 4 (emphasis in original).

Ibid 11. 


\section{The UNFCCC}

The UNFCCC is arguably the most important international treaty of relevance to climate change. The UNFCCC was agreed to in 1992 following the UN Conference on the Environment and Development held in Rio de Janeiro. It entered into force on 21 March 1994, and as at 2020, 197 countries have ratified it. ${ }^{84}$

While the 'ultimate aim' 85 of the UNFCCC is to prevent " dangerous" human interference with the climate system', ${ }^{86}$ it does not contain binding commitments to reduce greenhouse gas emissions by a specific amount by a specific date. However, it does anticipate more specific protocols and agreements to accomplish that result. ${ }^{87}$

The Preamble of the UNFCCC notes that

the largest share of historical and current global emissions of greenhouse gases has originated in developed countries, that per capita emissions in developing countries are still relatively low and that the share of global emissions originating in developing countries will grow to meet their social and development needs. ${ }^{88}$

The UNFCCC distinguishes between the responsibility and contributions of developed as compared with developing countries in art 4. Article 4(2)(a) of the UNFCCC commits developed country state parties to 'adopt national policies and take corresponding measures on the mitigation of climate change, by limiting its anthropogenic emissions of greenhouse gases and protecting and enhancing its greenhouse gas sinks and reservoirs'. ${ }^{89}$

\section{Kyoto Protocol}

The Kyoto Protocol was the first major international treaty to operationalise the UNFCCC by committing the parties to the Convention to reducing GHG emissions in accordance with stated targets. ${ }^{90}$ It was finalised in December 1997, ${ }^{91}$ but 'owing to a complex ratification process', ${ }^{92}$ it did not enter into force until February 2005. Currently, there are 192 Parties to the Kyoto Protocol.93

\footnotetext{
'What is the United Nations Framework Convention on Climate Change?', UNFCCC (Web Page) $<$ https://unfccc.int/process-and-meetings/the-convention/what-is-the-united-nationsframework-convention-on-climate-change>.

Ibid.

Ibid.

Dernbach and Kakade (n 63) 9.

UNFCCC (n 64) 2.

Ibid 12.

Kyoto Protocol (n 65).

Dernbach and Kakade (n 63) 10.

UNFCCC, 'What is the Kyoto Protocol?', Process and Meetings (Web Page) $<$ https://unfccc.int/kyoto_protocol>. Ibid.
} 
'Annex B' of the Protocol sets binding emission reduction targets for 37 developed countries and the European Union. ${ }^{94}$ State parties are obliged to meet their targets primarily through national measures. However, one significant aspect of the Kyoto Protocol was the establishment of additional market mechanisms by which state parties can meet targets emissions: Trading Schemes; the Clean Development mechanism (CDM); and 'Joint Implementation'. 95

The Kyoto Protocol also established monitoring and compliance systems, wherein State Parties' actual emissions are to be monitored and records kept of any trades. ${ }^{96}$ Specifically, the UN Climate Change Secretariat, based in Bonn, Germany, maintains an international transaction log to confirm transactions are consistent with the rules of the Protocol. 97 The Protocol's first commitment period was 2008 to 2012. All 37 countries that fully participated in the first commitment period complied with the Protocol.

\section{The Doha Amendment}

In Doha, Qatar, in December 2012, the Doha Amendment to the Kyoto Protocol was adopted, starting in 2013 and lasting until 2020. However, the Doha Amendment only recently came into effect. This is because 144 instruments of acceptance were required for entry into force of the amendment. In a 2013 letter to the Governments of the Kyoto Protocol Parties, the Secretary-General of the United Nations congratulated Parties on the adoption of the Amendment and encouraged its prompt acceptance..$^{9}$ In January 2018, the President of the Conference of the Parties $^{99}$ (the decision making body of the UNFCCC) and the Executive Secretary of the UNFCCC Secretariat, ${ }^{100}$ issued a joint letter to Parties to the Kyoto Protocol,

95 "The mechanism known as "joint implementation", defined in art 6 of the Kyoto Protocol, allows a country with an emission reduction or limitation commitment under the Kyoto Protocol (Annex B Party) to earn emission reduction units (ERUs) from an emission-reduction or emission removal project in another Annex B Party, each equivalent to one tonne of $\mathrm{CO} 2$, which can be counted towards meeting its Kyoto target': UNFCCC, 'Joint Implementation', Mechanisms under the Kyoto Protocol (Web Page) <https://unfccc.int/process/the-kyoto-protocol/mechanisms/jointimplementation>. 'What is the Kyoto Protocol?' (n 92).

Ibid.

See Letter from Ban Ki-moon to Governments that adopted the Doha Amendment, 13 February 2013 $<$ https://unfccc.int/files/kyoto_protocol/doha_amendment/application/pdf/sg_letter_doha_a mendment.pdf $>$.

99 UNFCCC, 'Conference of the Parties (COP)', Supreme Bodies (Web Page) $<$ https://unfccc.int/process/bodies/supreme-bodies/conference-of-the-parties-cop>.

100 UNFCCC, 'About the Secretariat', About Us (Web Page) <https://unfccc.int/about-us/what-is-theunfccc-secretariat>. 
again urging them to accept the Doha Amendment. ${ }^{101}$ By October 2020, the amendment had received the additional parties it needed to come into effect. ${ }^{102}$

The Doha Amendment included new commitments for the 'second commitment period' between 2013 and 2020, (the 'first commitment period' was between 2008 and 2012) and a revised reporting list of greenhouse gases, as well as technical amendments to wording that needed updating to account for the new commitment period. ${ }^{103}$ During the first commitment period, 37 industrialised countries and the European Community 'committed to reduce GHG emissions to an average of five percent against 1990 levels'. ${ }^{104}$ During the second commitment period, 'Parties committed to reduce greenhouse gas emissions by at least 18 percent below 1990 levels in the eight-year period from 2013 to 2020.' 105 However, the list of State Parties in the second commitment period is different from those in the first. ${ }^{106}$ Post-2020 obligations are addressed in the Paris Agreement.

\section{The Paris Agreement}

The landmark COP21 (the 21st Conference of the Parties) took place in Paris in 2015. The focus was upon a new agreement that would succeed the Kyoto Protocol in 2020, and set out the world's climate action plan for the remainder of the century. The Paris Agreement entered into force on 4 November 2016 (after ratification by at least 55 parties to the UNFCCC accounting for at least 55 percent of the total greenhouse gas emissions). ${ }^{107}$ The specific aim of the Paris Agreement is to keep 'a global temperature rise this century well below 2 degrees Celsius above pre-industrial levels and to pursue efforts to limit the temperature increase even further to 1.5 degrees Celsius'. ${ }^{108}$ The Paris Agreement seeks to do this by requiring all Parties to 'put forward their best efforts through "nationally determined contributions" (NDCs) and to strengthen these efforts in the years ahead' ${ }^{109}$ For example, arts 4 (1), (2), and (3) provide as follows:

Article 4(1). In order to achieve the long-term temperature goal set out in Article 2, Parties aim to reach global peaking of greenhouse gas emissions as soon as possible, recognizing that peaking will take longer for developing country Parties, and to

101 Letter from Frank Bainimarama and Patricia Espinosa to Governments party to the Kyoto Protocol, 7 January 2018 <https://unfccc.int/sites/default/files/resource/cop\%2023\%20pres\%20and\%20es \%200n\%20doha\%20amendment20180206-161356.pdf $>$. UNFCCC, 'The Doha Amendment', The Kyoto Protocol (Web Page) <https://unfccc.int/process/thekyoto-protocol/the-doha-amendment>.

'What is the Kyoto Protocol?' (n 95).

Ibid.

Ibid.

Ibid.

Paris Agreement (n 67).

UNFCCC, 'Key Aspects of the Paris Agreement', Process and Meetings (Web Page) <https://unfccc.int/process-and-meetings/the-paris-agreement/the-paris-agreement/keyaspects-of-the-paris-agreement $>$. Ibid. 
undertake rapid reductions thereafter in accordance with best available science, so as to achieve a balance between anthropogenic emissions by sources and removals by sinks of greenhouse gases in the second half of this century, on the basis of equity, and in the context of sustainable development and efforts to eradicate poverty.

Article 4(2). Each Party shall prepare, communicate and maintain successive nationally determined contributions that it intends to achieve. Parties shall pursue domestic mitigation measures, with the aim of achieving the objectives of such contributions.

Article 4(3). Each Party's successive nationally determined contribution will represent a progression beyond the Party's then current nationally determined contribution and reflect its highest possible ambition, reflecting its common but differentiated responsibilities and respective capabilities, in the light of different national circumstances. ${ }^{110}$

There are also requirements to report regularly on emissions. For example, art 13(7) of the Paris Agreement provides:

Each Party shall regularly provide the following information:

(a) A national inventory report of anthropogenic emissions by sources and removals by sinks of greenhouse gases, prepared using good practice methodologies accepted by the Intergovernmental Panel on Climate Change and agreed upon by the Conference of the Parties serving as the meeting of the Parties to this Agreement; and

(b) Information necessary to track progress made in implementing and achieving its nationally determined contribution under Article 4.111

The Paris Agreement has no mechanism for enforcing compliance. Instead, it relies on transparency to incentivise ongoing participation.

\section{Emissions Trading Schemes}

In addition to the various institutions and instruments described above, the law curriculum should include an explanation of the role played by emissions trading schemes ('ETS') in mitigating climate change.

An ETS puts a quantity limit and a price on emissions. ${ }^{112}$ The 'currency' of an ETS is emission units issued by the relevant government. ${ }^{113}$ Each unit is analogous to 'a voucher that allows the holder to emit one tonne of greenhouse gases'. ${ }^{114}$ In

\footnotetext{
$110 \quad$ Paris Agreement (n 67) arts 4(1)-(3).

$111 \quad$ Ibid art 13(7).

112 Catherine Leining, 'Climate Explained: How Emissions Trading Schemes Work and They Can Help Us Shift to a Zero Carbon Future', The Conversation (online, 28 August 2019) <https://theconversation.com/climate-explained-how-emissions-trading-schemes-workand-they-can-help-us-shift-to-a-zero-carbon-future-122325>.

113 Ibid.

$114 \quad$ Ibid.
} 
essence, emissions trading systems 'operate with the common currency of an emissions allowance'. ${ }^{115}$ By way of example, under the New Zealand Emissions Trading Scheme, the price for a tonne of greenhouse gases is currently around NZ\$25. ${ }^{116}$

\section{Domestic Legal Frameworks}

The law curriculum should include an examination of the legislative and political response to climate change by Australia and other countries. Most individual countries have enacted, or are in the process of enacting, legislation designed to acknowledge and recognise the need for action, and legal regulation thereof, on climate change. For example, Sweden, ${ }^{117}$ France, ${ }^{118}$ the UK, ${ }^{119}$ and Scotland, ${ }^{120}$ have passed laws to curtail carbon emissions. Suriname ${ }^{121}$ and Bhutan ${ }^{122}$ have reportedly declared themselves carbon negative. As noted above, New Zealand has passed legislation setting a net zero target.

In Australia there are several Federal government initiatives in response to climate change, although there is not yet national legislation in Australia setting a zero carbon target. On 25 February 2019, the Federal Government outlined its approach to action on climate change in the Climate Solutions Package. This included a commitment to direct investment in low-cost emissions abatement technology and clean energy through a climate fund. The focus of investment will shift away from wind and solar to storage and grid integration technologies. The Federal Government has made no commitment to carbon neutrality.

The state and territory governments have been more proactive: South Australia enacted the Climate Change and Greenhouse Emissions Reduction Act in 2007 and was the first Australian state to legislate targets to reduce GHG

Dernbach and Kakade (n 63) 12-13.

Leining (n 112).

Sweden introduced a Climate Act in 2018: See 'Sweden's Climate Act and Climate Policy Framework', Swedish Environmental Protection Agency (Web Page, 26 October 2020) <http://www.swedishepa.se/Environmental-objectives-and-cooperation/Swedish-environmental -work/Work-areas/Climate/Climate-Act-and-Climate-policy-framework-/>; See also 'The Swedish Climate Act', European Climate Initiative (Web Page, 19 December 2018) <https://www .euki.de/wp-content/uploads/2019/09/20181205_SE_Swedish-Climate-Act_Study.pdf >.

The French Parliament enacted the Energy and Climate Act of 8 November 2019 following validation by the Conseil constitutionnel [French Constitutional Council], decision $n^{\circ}$ 2019-791 DC, 7 November 2019 reported in JO, 9 November 2019.

In the United Kingdom, the Climate Change Act 2008 established the 'Independent Committee on Climate Change'. Section 1 of that Act sets a net UK carbon account target. See Leining (n 112); Climate Change Act 2008 (UK).

In Climate Change (Emissions Reduction Targets) (Scotland) Act 2019 (Scot), s 1(2) of the Act sets the 'zero-emissions target' as 2045.

UN News, 'Suriname's Climate Promise, For a Sustainable Future', Climate and Environment (Web Page, online, 31 January 2020) <https://news.un.org/en/story/2020/01/1056422>.

Climate Council, 'Bhutan is the World's Only Carbon Negative Country, So How Did They Do It?', Climate Leaders (Web Page, 2 April 2017) <https://www.climatecouncil.org.au/bhutan-is-theworld-s-only-carbon-negative-country-so-how-did-they-do-it/>. 
emissions; in 2008 the Tasmanian Parliament passed the Climate Change (State Action) Act; the ACT enacted the Climate Change and Greenhouse Gas Reduction Act in 2010; and in 2017 Victoria passed the Climate Change Act 2017 (Vic). ${ }^{123}$ All Australian states and territories have committed to a target of net zero emissions by 2050 at the latest.

At the time of writing, Independent Member of Parliament, Zali Steggal, has proposed Australia enact a Climate Change Act at the Federal level, and the Climate Change (National Framework for Adaptation and Mitigation) Bill 2020 is currently before the House of Representatives. The available draft proposes a zero emissions target of 2050.124

Even in the absence of specific climate legislation, lawyers and petitioners have engaged with planning and environmental legal frameworks and with relevant human rights frameworks to pursue climate change mitigation and adaption. This will be discussed further below in the context of the broader impacts and implications of climate change on the law in general, and the need for law schools to include engagement with these developments in the law curriculum.

\section{B Climate Change and the Law: The Broader Impacts of Climate Change}

The consequences of climate change for human wellbeing are such that efforts to address the issue also raise important questions about the nature of the relationship between the state and the individual, between state and federal governments, and between countries. In this sense, climate change law has implications for constitutional law, administrative law, dispute resolution and, in the context of negligence and other torts, private law too. It is also 'likely to be relevant to insurers ... international bodies concerned with threats to peace and security ... and domestic energy retailers' ${ }^{125}$ The reality is that

devising legal solutions to climate change is likely to involve profound changes to existing governance and regulatory frameworks, with reverberations felt in many other areas of law ...126

In the Australian context, the absence of federal constitutional rights relating to life, health, and the environment, and the absence of any meaningful federal climate change legislation or other legal framework, mean that climate-related

123 Victoria State Government, 'Climate Change Act 2017', Legislation (Web Page, 23 September 2020) <https://www.climatechange.vic.gov.au/legislation/climate-change-act-2017>. See Climate Change Act 2017 (Vic).

${ }_{124}$ 'Climate Change (National Framework for Adaptation and Mitigation) Bill 2020', Zali Steggall OAM MP (Web Page, 9 January 2020) <https://www.zalisteggall.com.au/climate_change_national_ framework_for_adaptation_and_mitigation_bill_2020>.

125 Peel (n 62) 923-4.

126 Ibid 924. 
legal action often takes place in the context of planning and administrative law. It has been observed:

In Australia, the more common approach has been to bring public law actions for judicial or merits review, challenging government decision-making on the basis that environmental impact studies for particular developments have inadequately considered potential climate change impacts. ${ }^{127}$

By way of example, in Charles and Howard Pty Ltd $v$ Redland Shire Council, 128 it was held that a Judge of the Queensland Planning and Environment Court was

entitled, as he did, to take into account ... the impact of climate change on sea levels on the area proposed ... and to accept ... [that the] building site may be vulnerable to rising sea levels because of climate change ...129

Notably, and perhaps surprisingly, outside of the United States of America ('USA'), Australia reportedly records the highest number of climate litigation cases. ${ }^{130}$

Constitutional law and human rights law, and the teaching of those subjects, are also impacted by climate change. In federal systems, constitutional issues may arise in terms of responsibility for action/inaction on the part of state and federal governments, and in countries with constitutional bills of rights, the legal consequences may be significant in a litigation context. A number of human rights, not least the right to life, ${ }^{131}$ the right to health, ${ }^{132}$ and rights to food and water, ${ }^{133}$ will be affected by climate change. In the State of the Netherlands (Ministry of Economic Affairs and Climate Policy) v Stichting Urgenda, ${ }^{134}$ the Supreme Court of the Netherlands considered the obligations of the State of the Netherlands under arts 2 and 8 -which relate, respectively, to the right to life and the right to private and family life - of the European Convention on Human Rights ('ECHR').135 In December 2019, the Supreme Court upheld an order directing the State to reduce greenhouse gases by the end of 2020 by at least $25 \%$ compared to $1990 .{ }^{136}$ In a

Ibid 956. See also reviews of relevant cases undertaken in Jacqueline Peel, 'The Role of Climate Change Litigation in Australia's Response to Global Warming' (2007) 24(2) Environmental and Planning Law Journal 90. (2007) 159 LGERA 349. Ibid 359 [28].

Joana Setzer and Rebecca Byrnes, Global Trends in Climate Change Litigation: 2019 Snapshot (Policy Report, July 2019) 3 <http://www.lse.ac.uk/GranthamInstitute/wp-content/uploads/2019/07/GRI Global-trends-in-climate-change-litigation-2019-snapshot-2.pdf>.

International Covenant on Civil and Political Rights, opened for signature 16 December 1966, 999 UNTS 171 (entered into force 23 March 1976) art 6.

Ibid art 12 .

International Covenant on Economic, Social and Cultural Rights, opened for signature 16 December 1966, 999 UNTS 3 (entered into force 3 January 1976) arts 11-12.

Hoge Raad der Nederlanden [Supreme Court of the Netherlands], 19/00135 ECLI:NL:HR:2019:2007, 20 December 2019 ('Urgenda').

Convention for the Protection of Human Rights and Fundamental Freedoms, opened for signature 4 November 1950, 213 UNTS 221 (entered into force 3 September 1953) arts 2, 8.

Urgenda (n 134). 
summary attached to the English translation of the judgment, it is noted the Court found as follows:

The Netherlands is a party to the United Nations Framework Convention on Climate Change (UNFCCC). The objective of that convention is to keep the concentration of greenhouse gases in the atmosphere to a level at which a disruption of the climate system through human action can be prevented. The UNFCCC is based on the premise that all member countries must take measures to prevent climate change ... Each country is thus responsible for its own share. That means a country cannot escape its own share of the responsibility to take measures by arguing that compared to the rest of the world, its own emissions are relatively limited in scope and that a reduction of its own emissions would have very little impact on a global scale. The State is therefore obliged to reduce greenhouse gas emissions from its territory in proportion to its share of the responsibility. This obligation of the State to do 'its part' is based on Articles 2 and 8 of the ECHR, because there is a grave risk that dangerous climate change will occur that will endanger the lives and welfare of many people in the Netherlands. ${ }^{137}$

In February 2021, a court in France found the French State had failed to address the climate crisis and had not fulfilled its promises to tackle greenhouse gas emissions. ${ }^{138}$ The court ruled that the applicants in that case were entitled to seek compensation in kind for the ecological damage caused by that failure.

At the international level, the link between human rights law and climate change has been acknowledged by the United Nations Human Rights Council. In a 2016 'Report of the Special Rapporteur on the Issue of Human Rights Obligations Relating to the Enjoyment of a Safe, Clean, Healthy and Sustainable Environment', 139 it was observed that 'human rights norms clarify how States should respond to climate change. ${ }^{140}$ Immigration and refugee law will also be impacted, due to the likelihood of 'peoples from low-lying island nations ... [being] rendered homeless and stateless if sea levels continue to rise' ${ }^{141}$

As was briefly noted above, the potential for legal action is not, however, limited to the public law sphere. Rather, '[c]limate change is coming to the common law.' ${ }^{142}$ This could take the form, for example, of private law actions 'brought in negligence or nuisance against large industrial polluters'. ${ }^{143}$ These claims would be made 'against carefully composed groups of greenhouse gas

Ibid [5.6.1]-[5.8].

Administrative Court of Paris [Tribunal Administratif de Paris], 'The Case of the Century', Tribunal News (Press Release, 3 February 2021) <http://paris.tribunal-administratif.fr/Actualites-duTribunal/Communiques-de-presse/L-affaire-du-siecle>. See also Kim Willsher, 'Court Convicts French State for Failure to Address Climate Crisis', The Guardian (online, 4 February 2021) $<$ https://www.theguardian.com/environment/2021/feb/03/court-convicts-french-state-forfailure-to-address-climate-crisis?cmp=share_iosapp_other $>$.

Report of the Special Rapporteur on the Issue of Human Rights Obligations Relating to the Enjoyment of a Safe, Clean, Healthy and Sustainable Environment, UN GAOR, UN Doc A/HRC/31/52 (1 February 2016). Ibid $\mathrm{pt} \mathrm{V}[86]$.

Peel (n 62) 931.

Douglas A Kysar, 'What Climate Change Can Do about Tort Law' (2011) 41(1) Environmental Law 1, 2. Peel (n 62) 956. 
emitting defendants, seeking monetary damages and injunctive relief to lessen the threat and financial burden of climate change's harmful impacts. ${ }^{144}$ In terms of identifying the duty owed in the context of a tort, it has been argued that a duty attached at the time the UNFCCC entered into force. ${ }^{145}$ There is still room for controversy in terms of proving causation, but as scientific consensus consolidates, this may start to prove less problematic.

Climate change has implications for most, if not all, law subjects taught in the law curriculum. This is not least because the regulatory tools required by climate change necessarily draw on a wide range of areas of law, including, but not limited to, 'administrative law, property law, tort law, corporations law, human rights law and international law'. ${ }^{146}$

Ultimately, the debate on climate change is premised on a basic question: 'what do we do with the information in front of us?' 147 The same question can be asked in the specific context of legal education. What do legal educators do with the information in front of them? How do legal educators prepare students for

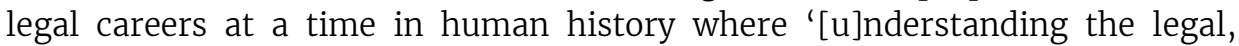
scientific, and other trends in climate change is as essential for lawyers as it is for their clients'?148 One answer, among many, is the inclusion of climate change in the law curriculum; not simply as a one off isolated elective, but woven throughout various stages of a degree program.

In the following, final section of the article we consider additional ways in which law schools can, and already are, incorporating climate change law into the curriculum.

\section{Climate Change LaW in the CuRriculum}

In the first part of the article we presented the range of factors motivating law schools to respond to climate change by, inter alia, including climate change law in the curriculum. These include the social obligation of law schools to serve the public good as well as the expectations of the community and demands from employers for graduates with expertise in an emergent practice area. As Mehling et al recently explained:

As climate change mitigation and adaptation rise in importance, so should demand for legal expertise in government bureaucracies and international organisations, the judiciary, private corporations, civil society and interest groups, and traditional law firms and

Kysar (n 142) 2.

See, eg, Benito Müller, Niklas Höhne and Christian Ellermann, 'Differentiating (Historic) Responsibilities for Climate Change' (2009) 9(6) Climate Policy 593, 595; Kysar (n 142) 10.

Peel (n 62) 927.

Dernbach and Kakade, (n 63) 2.

Ibid 31. 
consultancies. Accompanying that demand is a growing interest in relevant courses and academic credentials through which to build and document climate law expertise. ${ }^{149}$

How should law schools respond to this pressure? As explained in the previous section, climate change law intersects with, and encroaches upon, a variety of legal subject areas. In this section we consider the incorporation of climate change law into the law curriculum by way of discrete, dedicated subjects and programs.

\section{A Climate Change Law Subjects}

In the past, climate change and climate change law were, at best, considered to be specific topics in environmental law subjects and chapters in environmental law textbooks. Now, there is an increasing number of degree programs and subjects, ${ }^{150}$ textbooks, ${ }^{151}$ and dedicated journals ${ }^{152}$ focussing upon climate change law. ${ }^{153}$ While some scholars have questioned the existence of, or the need for, 'climate change law' as a discrete field of scholarship or practice, ${ }^{154}$ it is clear that it is emerging as a discrete new subject area within the law curriculum. ${ }^{155}$

In his contribution to the UWA Public Policy Institute's The Preparedness Report, David Hodgkinson helpfully outlined the possible content of a climate change law subject:

[A]n intensive three- or five-day climate change law course could, in part, involve the international climate change regime, consisting of: (a) the United Nations Framework Convention on Climate Change; (b) its Kyoto Protocol; (c) the 2015 COP21 Paris Agreement; and (d) subsequent developments.

Other matters to consider in any such course could include: geo-engineering (or bio-energy with carbon capture and storage [BECCS]); Australian climate change law and policy (including the Commonwealth and the states and territories); the National

Michael Mehling et al, 'Teaching Climate Law: Trends, Methods and Outlook' (2020) 32(3) Journal of Environmental Law 417, 418.

150 See below nn $156-70,172-6$.

See, eg, Daniel Bodansky, Jutta Brunnée and Lavanya Rajamani, International Climate Change Law (Oxford University Press, 2017); Daniel A Farber and Cinnamon P Carlarne, Climate Change Law (Foundation Press, 2018); Richard G Hildreth et al, Climate Change Law: Mitigation and Adaptation (West Academic, 2009); Leonardo Massai, European Climate and Clean Energy Law and Policy (Routledge, 2011); John R Nolon and Patricia E Salkin, Climate Change and Sustainable Development Law in a Nutshell (West Academic, 2010); Hari M Osofsky and Lesley K McAllister, Climate Change Law and Policy (Aspen Publishers, 2012); Chris Wold, David Hunter and Melissa Powers, Climate Change and the Law (LexisNexis, $2^{\text {nd }}$ ed, 2013); Edwin Woerdman, Martha Roggenkamp and Marijn Holwerda (eds), Essential EU Climate Law (Edward Elgar, 2015); Benoit Mayer, The International Law on Climate Change (Cambridge University Press, 2018).

152 See, eg, Lexxion, Carbon \& Climate Law Review; Brill, Climate Law; University of San Diego, San Diego Journal of Climate \& Energy Law; Washington and Lee University, Washington and Lee Journal of Energy, Climate, and the Environment.

$153 \quad$ Mehling et al (n 149) 417.

154 Bodansky, Brunnée and Rajamani (n 151) 11; JB Ruhl and James Salzman, 'Climate Change Meets the Law of the Horse' (2013) 62(5) Duke Law Journal 975, 1013. 
Greenhouse and Energy Reporting Scheme; the Emissions Reduction Fund (ERF) and its safeguard mechanism; carbon capture and storage; decarbonising cities and lowcarbon sustainable precincts; and the ethics of climate change law and policy.

Learning outcomes could include: the critical analysis of instruments available to address the climate change problem, both in Australia and internationally; understanding the interaction between climate change law and policy, both in unitary and federal systems; and demonstrating an understanding of the ethical underpinnings of climate change law and policy, both at national and international levels.

Outcomes could also include the development of key analytical skills through comparison of climate change law at local, state and federal levels (as appropriate), and the drafting of outline agreements that address particular climate change-related problems. ${ }^{156}$

Several Australian law schools now offer climate change law electives. These include the following:

- The Australian National University ('ANU') offers an intensive subject, Climate Change Vulnerability and Adaption, ${ }^{157}$ which looks at climate change from a scientific, societal and policy perspective.

- The University of Queensland ('UQ') has in the past offered a postgraduate Climate Change Law and Policy subject that dealt with the legal and practical issues raised by climate change in Australia and around the world. ${ }^{158} \mathrm{UQ}$ also offers an International Regulatory Frameworks for Climate Change \& Environmental Management subject which, although run by the School of Earth and Environmental Sciences, explores the role of regulatory frameworks created by international law, governance and policy in solving shared international environmental problems. ${ }^{159}$

- The University of Western Australia offers an elective subject on Climate Change Law and Emissions Trading. ${ }^{160}$ The subject examines the Australian Government's clean energy legislation, issues for the various state governments, emissions trading schemes and carbon taxes more generally, and the international context in which they operate. Policy issues are also addressed.

David Hodgkinson, 'Mitigation of Climate Change: Law, Policy and Ethics' in Shamit Saggar and Anna Zenz (eds), The Preparedness Report (UWA Public Policy Institute, 2020) 27, 31. Australian National University, 'Climate Change Vulnerability and Adaptation', Programs and Courses (Web Page, 2021) <https://programsandcourses.anu.edu.au/2021/course/ENVS8003>. The University of Queensland, 'LAWS7978: Climate Change Law and Policy', Course Profiles (Web Page) <https://course-profiles.uq.edu.au/student_section_loader/section_2/45123>.

The University of Queensland, 'ENVM7124: International Regulatory Frameworks for Climate Change \& Environmental Management', Course Profiles (Web Page) <https://courseprofiles.uq.edu.au/student_section_loader/section_2/108722>.

The University of Western Australia, 'LAWS5521 Climate Change Law and Emissions Trading', Unit Details (Web Page) <https://handbooks.uwa.edu.au/unitdetails?code=LAWS5521>. 
- The University of Sydney offers Climate Justice and Disaster Law, which examines recent law and policy initiatives from developed to developing countries, such as the establishment of the UNFCCC and the Paris Agreement. ${ }^{161}$ The subject details human and non-human climate justice and its application across all stages of disaster: prevention, response, recovery, compensation and risk transfer.

- The University of Melbourne also offers two subjects in Climate Change Law that deal with the laws and regulations covering domestic, comparative and international legal dimensions. Topics addressed in the first subject include the multidisciplinary nature of climate law study, structures for climate change governance at the international and domestic levels, modes of climate change regulation such as emissions trading schemes and renewable energy targets, litigation and its role in securing climate justice, and legal frameworks for climate change adaptation. ${ }^{162}$ The second subject examines the UNFCCC and the associated Paris Agreement, and questions how international agreements can be translated into federal and state legislative responses to mitigation and adaptation, and their effects on Indigenous peoples. ${ }^{163}$

- The University of Adelaide offers several undergraduate and postgraduate subjects that concern environmental law generally, as well as climate change more specifically. Climate Change Law is an undergraduate subject that engages with legal regimes, approaches and responses to climate change at the international and national level from the UNFCCC to Australian federal, state and local legislation. ${ }^{164}$ It also considers the broader scientific, policy, ethical and normative debates that overlay and add context to the legal measures and solutions undertaken to mitigate and adapt to climate change. The postgraduate subject International Environmental Law deals with the role of international law in addressing global environmental problems, in particular climate change and the protection of biological diversity. ${ }^{165}$

- Monash University offers an undergraduate International Environmental Law subject that outlines the broad political challenges raised by the

The University of Sydney, 'Climate Justice and Disaster Law: LAWS6320', Unit of Study (Web Page, 2021) <https://www.sydney.edu.au/courses/units-of-study/2021/laws/laws6320.html>.

The University of Melbourne, 'Climate Change Law (LAWS50056)', Subjects (Web Page, 11 February 2021) <https://handbook.unimelb.edu.au/2021/subjects/laws50056>.

The University of Melbourne, 'Climate Change Law (LAWS70293)', Subjects (Web Page, 11 February 2021) <https://handbook.unimelb.edu.au/2021/subjects/laws70293>.

The University of Adelaide, 'LAW 2568:Climate Change Law', University Course Planner (Web Page) $<$ https://access.adelaide.edu.au/courses/details.asp?year $=2019$ \& course $=108949+1+3920+1>$.

The University of Adelaide, 'LAW 7040: International Environmental Law (PG)', Course Outlines (Web Page) <https://www.adelaide.edu.au/course-outlines/103837/1/quad-4/2019/>. 
global environmental crisis both in the developed and developing world. ${ }^{166}$ The postgraduate subject The Law of Climate Change examines Australia's response to climate change at national and state levels and compares it to examples in foreign jurisdictions such as the European Union, America, and Asia. ${ }^{167}$

- The University of New South Wales ('UNSW') offers a Climate Law postgraduate subject. The subject examines the origins, evolution and practice of international climate change law, tracing it through to domains normally associated with private law and markets. It begins with an overview of the scientific, economic and normative debates about climate change and then examines the Australian and international legal regimes related to climate change. This includes the UNFCCC, the Kyoto Protocol and more recent negotiations. The subject examines ongoing debates about national emissions regulations, as well as more localised attempts to build a low emissions economy. It provides international comparisons to better situate Australia's legal regime.

- The University of Newcastle has in the past offered the subject Climate Change Law and Justice. ${ }^{168}$ Aspects of international law and policy were considered, as well as the Paris Agreement and UNFCCC, from a legal and economic perspective. Environmental economics theory, its application to climate change policy, and environmental taxes and emissions trading were also studied. The University of Newcastle also offered a similar subject in International Climate Change Law and Policy, where students learned about the evolution and architecture of international law and the various policies and regulations put in place to combat climate change.

- The University of Technology Sydney ('UTS') offers the subject Climate Law and Carbon Markets that examines the existing and emerging legal rules and frameworks both internationally and in Australia, as well as the impacts of these on business and the response from industry. ${ }^{169}$

- The University of Tasmania offers the elective subject Climate Change Law and Policy within its LLB. ${ }^{170}$ This subject looks at climate change mitigation and adaptation at all levels, the science of climate change, and

Monash University, 'LAW4313: International Environmental Law', 2021 Handbook (Web Page) <https://handbook.monash.edu/2021/units/LAW4313>.

Monash University, 'LAW5389: The Law of Climate Change', 2021 Handbook (Web Page) $<$ https://handbook.monash.edu/2021/units/LAW5389?year=2021>.

The University of Newcastle, 'LAWS5038 Climate Change Law and Justice', Course Handbook (Web Page) <https://www.newcastle.edu.au/course/LAWS5038>.

University of Technology Sydney, '76041 Climate Law and Carbon Markets', Handbook 2021 (Web Page, 7 March 2021) <http://handbook.uts.edu.au/subjects/76041.html>.

University of Tasmania, 'Climate Change Law and Policy LAW656', Courses \& Units (Web Page, 14 July 2020) <https://www.utas.edu.au/courses/cale/units/law656-climate-change-law-and-policy>. 
the consequences likely to occur environmentally, socially and economically. The subject also considers the strategies that have been put in place to address greenhouse gas emissions, as well as the Kyoto Protocol and other legal developments.

\section{B Climate Change Law Programs}

According to Mehling et al, teaching climate change law requires 'a generalist perspective to capture its sprawling horizontal scale and manifold linkages' and 'a specialist perspective to reflect its vertical layers and complex technicalities'. ${ }^{171}$ A thorough approach to inculcating an understanding of climate change and its impacts upon the law arguably requires far more than a single subject.

Several universities in Australia now offer graduate diplomas and Master of Laws degrees specifically relevant to climate change and the law.

- The ANU offers a Master of Climate Change (Environmental Science). This degree is a two-year graduate degree offered by the ANU College of Asia and the Pacific and covers climate change policy including adaption and vulnerability, as well as having a law elective option. ${ }^{172}$

- The University of Sydney offers a Master of Laws in Environmental Law and a Graduate Diploma in Environmental Law. Across both programs, subjects include Climate Justice and Disaster Law (described above); Environmental Law and Policy; Environmental Litigation; Pollution, Corporate Liability and Government; and Energy and Water Security Law. The University of Sydney also offers a Master of Environmental Science and Law. ${ }^{173}$ The one-and-a-half-year program allows study in complementary subjects across both environmental science and environmental law, and is designed primarily for science graduates looking to engage with environmental policy and regulation.

- The University of Melbourne offers a Master of Environment Law.174 The subjects within the program are focused on emerging national and international legal issues and practices such as water law, climate change law, animal law, waste management and general planning and development. Other areas include the negotiation of international

Mehling et al (n 149) 419 .

Australian National University, 'Master of Climate Change', Programs and Courses (Web Page) <https://programsandcourses.anu.edu.au/2020/program/MCLCH>.

The University of Sydney, 'Master of Environmental Science and Law', Courses (Web Page) <https://sydney.edu.au/courses/courses/pc/master-of-environmental-science-and-law.html>. The University of Melbourne, 'Master of Environmental Law', Study (Web Page) <https://study. unimelb.edu.au/find/courses/graduate/master-of-environmental-law/>. 
environmental treaties and the laws surrounding international 'commons' areas such as Antarctica, the high seas and outer space.

- UNSW offers a Master of Environmental Law and Policy that includes six compulsory and six elective subjects including climate change law subjects. ${ }^{175}$

- The University of Newcastle offers a Master of Laws in Environmental Law that includes several climate change law subjects. ${ }^{176}$

To date only one Australian University offers an undergraduate program that focuses upon climate change and the law.

\section{Bond University: Double Major in Climate Law}

In 2021, Bond University launched the LLB (Climate Law). ${ }^{177}$ The new program provides a mechanism for climate law and practice to be taught to those seeking the knowledge, skills and professional qualification to be maximally effective in understanding and addressing climate change and its consequences. The LLB (Climate Law) is an eight-semester full-time undergraduate program that combines the usual compulsory LLB subjects with climate change law subjects and non-law subjects relevant to climate change, and which satisfies the academic requirements for admission as a legal practitioner. ${ }^{178}$ LLB students in this program have three options:

1 A Specialisation in Climate Law by completing four of the nine climate law subjects.

2 A Major in Climate Law by completing six of the nine climate law subjects.

3 A Double Major in Climate Law by completing all 12 climate law and non-law subjects.

UNSW Sydney, 'Master of Environmental Law and Policy', Degrees (Web Page) <https://www.law. unsw.edu.au/degree/master-environmental-law-and-policy>. $<$ https://www.newcastle.edu.au/degrees/master-environmental-law>.

177 Jordan Baker, "We Need People Who Are Trained": University Offers First Climate Change Law Degree', The Sydney Morning Herald (online, 10 December 2020) <https://www.smh.com.au/ national/we-need-people-who-are-trained-university-offers-first-climate-change-lawdegree-20201210-p56mco.html>.

${ }_{178}$ Bond University, 'Become a Climate Law Specialist and Advocate for Climate Reform', Specialise in Climate Law (Web Page) <https://bond.edu.au/LLB-climate-law>. 


\begin{tabular}{|l|l|}
\hline Climate law subjects & $\begin{array}{l}\text { LAWS13-121 Climate Law in Context } \\
\end{array}$ \\
\hline & $\begin{array}{l}\text { LAWS13-122 Law Reform and Critical } \\
\text { Consciousness }\end{array}$ \\
\hline & LAWS13-123 Wild Law Jurisprudence \\
\hline & $\begin{array}{l}\text { LAWS13-124 Climate Change and Natural } \\
\text { Resources Law }\end{array}$ \\
\hline & LAWS13-125 Negotiating Climate Disputes \\
\hline & $\begin{array}{l}\text { LAWS13-126 Climate Change and Human } \\
\text { Rights }\end{array}$ \\
\hline & $\begin{array}{l}\text { LAWS13-127 Climate Liability and Risk } \\
\text { Management }\end{array}$ \\
\hline & $\begin{array}{l}\text { LAWS17-219 International Emissions Trading } \\
\text { Law }\end{array}$ \\
\hline & $\begin{array}{l}\text { LAWS17-557 International Environmental } \\
\text { Law }\end{array}$ \\
\hline $\begin{array}{l}\text { Climate non-law } \\
\text { subjects }\end{array}$ & \begin{tabular}{l} 
WorE11-100 Climate Change and the Future \\
\hline \\
SSUD11-102 Sustainable Development and \\
\hline
\end{tabular} \\
\hline & $\begin{array}{l}\text { SSUD11-105 Land Economy and the } \\
\text { Environment }\end{array}$ \\
\hline
\end{tabular}

The target market for the program is predominantly undergraduate students primarily school leavers - who wish to contribute to addressing climate change by leading regulatory reform. Interest in the program to date has been strong, consistent with the findings of the recent study by Cambridge International (referred to earlier) that young people around the world are deeply concerned about climate change. ${ }^{179}$ The institution also has plans to introduce an LLM in Climate Law.

\section{CONCLUSION}

Climate change is one of the most pressing challenges facing the global community, and law schools have an important role to play in preparing law graduates to assist with mitigating and addressing the causes and consequences of climate change. The community does not only need more climate scientists and social workers; it also needs lawyers who understand climate change and how to

179 Will Nott, 'Students Deeply Concerned About Climate Crisis', The Pie News (Web Page, 3 March 2020) <https://thepienews.com/news/students-deeply-concerned-about-climate-crisis/>. 
work with our legal and political systems so that we can respond appropriately to climate change.

In this article, we have argued that law schools have a specific obligation to ensure law students are educated in climate change law during the course of their studies, not least because a) law schools and universities have an obligation to contribute to the public good; and b) in order to be job ready at this time in human history, law graduates must understand the impacts of climate change on law and regulation and the ensuing regulatory responses. To contextualise this need, we examined the landscape of climate change law and the implications of climate change for the law generally. Finally, we offered examples of ways in which law schools can incorporate climate change law into their law programs.

A law degree that includes a focus upon climate change law will provide students with the qualifications and the expertise they need to take effective action. Such a degree will be of interest not only to those already thinking about studying law and attracted to the idea of becoming a specialist in an emerging area of legal practice. It may also appeal to the student who perhaps has never considered studying law before but who wants to do something about climate change. A law degree that includes a focus upon climate change and the law will empower its graduates to go out and make a difference. It will give students committed to helping the community adapt and respond to climate change the tools they need to lead legal, social and political reform. And by providing such a program, law schools will once again be fulfilling their commitment to serve the public good. 